\title{
Including prospective tenants and homeowners in the urban development process in Finland
}

\author{
Dr. Matti Kuronen \\ Aalto University, Real Estate Business research group \\ matti.kuronen@aalto.fi \\ P.O. Box 11200, 00076 AALTO, Finland \\ mob. +358 405769105 \\ Dr. Wisa Majamaa \\ ICECAPITAL Real Estate Management Ltd., Finland \\ Dr. Peter Raisbeck \\ University of Melbourne, Faculty of Architecture, Building and Planning \\ Dr. Chris Heywood \\ University of Melbourne, Faculty of Architecture, Building and Planning
}

\begin{abstract}
The twofold purpose of this paper is to establish the prospective inhabitants as a part of the development process, and to provide an overview of participatory planning in the context of Finnish urban residential Public-Private Partnerships (PPPs). This overview examines how the future inhabitants of new residential developments can contribute to informed decision-making within a PPP framework.

Communicative planning theory serves as a framework to compare the urban development process from the point of view of future inhabitants. Finnish case studies are used to compare the traditional public-led processes with processes based on PPPs. This comparison is discussed within the context of PPPs and how they may evolve further and develop into a Public-Private-People Partnership (4P) model.

The examination of the case studies suggests that involving future inhabitants as stakeholders in the urban planning development process would lead to and require new methods of participation. These methods potentially impact the PPP process as a whole and on several levels. In the Finnish examples discussed here, these range from elements of general planning to individual house design.

The research, whilst drawing on the broad field of PPP research, is based on Finnish case studies only. However, this research suggests that the 4P approach is a practical model which may fill the gap between international PPP theory and local, practical solutions for the planning of urban development, both in Finland and elsewhere. Future research can look at this model in other PPP jurisdictions and contexts.
\end{abstract}


The $4 \mathrm{P}$ model can be used to establish new methods to plan and develop local infrastructure which meets the needs of future inhabitants.

The findings of this paper emphasise the crucial role of future inhabitants in the PPP process. The conclusions points out the possibilities for broad and open participation in urban planning and development processes. The $4 \mathrm{P}$ model is found to be a potentially valuable theoretical and practical concept for use in PPP urban developments.

\section{Keywords}

Participation

Public-Private Partnerships (PPPs)

Public-Private-People Partnership (4P)

Urban Development

Urban Planning 


\section{Introduction}

Changes in patterns of work and workplaces at a global level have affected housing issues at local and regional levels (Castells, 1996; Kotler et al, 1999; Kotler \& Lee, 2007'). In this global context Finland can be seen as an immature urban system, because in Finland the level of urbanisation is over 20 percentage points lower than in, for example, its Scandinavian siblings Sweden and Denmark (United Nations Population Division, 2007). However, this situation is changing with increasing migration to urban areas, especially to the Helsinki region. Indeed, the Helsinki region is now one of the fastest growing metropolitan areas in Europe. It has been predicted that in the next 40 years the region's population will grow from the present 1.3 million to 1.7 or even 1.8 million (City of Helsinki Urban Facts, 2010). Clearly, this kind of growth will require significant investments in infrastructure and services that will be hard to fund with existing tax revenues.

One option to emerge in recent years as a means to relieve the pressure on tax revenues in providing social infrastructure is to use Public-Private Partnerships (PPPs) and land use contracts to share the costs of development and rapid growth. While PPPs are seen as a financial device to relieve that pressure, they developed within an approach to public administration known as New Public Management (NPM) (Aulich et al, 2001; Corrigan and Joyce, 1997). This approach arose from concerns that public administration was considered moribund and inefficient and that the solution was to separate policy making ('steering') from service delivery or doing ('rowing') (Osborne and Gaebler, 1992).

Among the characteristics of NPM (after Aulich et al, 2001; Van Gramberg and Teicher, 2000; Corrigan and Joyce, 1997), the following are some of the most salient:

- Pursuit of greater efficiencies in the use of public funds;

- Preference for private-sector models of management, such as adopting strategic business planning, internal trading arrangements within the public sector, emphasis on the public as customers and as consumers of services, and more; and

- Opportunities for non-public-sector modes of social infrastructure provision created by the separation of policy and service delivery. And consequently, a move to private ownership, contracting out and contestability of service delivery - all evident in PPPs.

NPM is most evident in English-speaking countries and less marked in non-English-speaking OECD countries (Aulich et al, 2001), but not unknown, as is evident in this study in Finland.

In PPPs, project and financial risk is theoretically allocated to those partners most able to manage that particular form of risk (Thobani, 1998; Grimsey and Lewis, 2002; Martinus et al, 2006; Nisar, 2007). While the social infrastructure is intended to deliver benefits to the people, it is rare that they play any part in what might be considered 'traditional' PPPs (Mattar \& Cheah, 2006; Trentmann, 2007; El-Gohary et al, 2006), despite the customer orientation that is inherent in NPM. It is the inclusion of these people - the $4^{\text {th }}$ ' $P$ ' - that is of interest to this paper. The people's influence on risk and cost-benefit allocations are also examined through examples drawn from the case study areas.

In Finland, PPPs and special land use contracts have been used to speed up urban development processes and to finance infrastructure for new residential areas. Land use contracts, whereby infrastructure costs are divided between private landowners and the municipality, which is in charge 
of delivering infrastructure, have been widely used in Finland, even before they were written into the Land Use and Construction Act. Social infrastructure costs, including the buildings needed for public services, like schools and kindergartens, and associated infrastructure, like roads and water supply, have been partly financed by land use contracts.

The role of prospective inhabitants in Finland's urban planning and wider urban development processes requires consideration in this context. The thinking that underpins this paper points to a new $4 \mathrm{P}$ model for the urban planning and procurement of new residential areas with their associated infrastructure. By comparing multiple master-planned areas under development in the Helsinki metropolitan area, we establish the role of future inhabitants in the participatory planning of new residential areas delivered through the Public-Private-People Partnership (4P) model. One of the case study areas is examined more closely to establish the practical solutions for economic and social infrastructure development.

Some recent research on urban residential development in Finland (Kuronen \& Majamaa, 2006; Kuronen et al, 2011) indicates that future inhabitants can, and must, be identified as important stakeholders in the frameworks and applications which govern communicative planning theory and its applications. This is because, after development and construction delivery, they will use the planned area and live there. They are the primary end-users of the area, along with its economic and social infrastructure, and their opinions and attitudes are vital for the area to function as a residential location and community. Including the end-users as stakeholders in the development process allows a number of important real-life questions to be answered that are of concern to these future residents. Examples of such questions are the location of the nearest school or kindergarten, fear of commuting in traffic jams, housing costs and perhaps a need for a second car. Because answers to questions such as these are crucial to the success of the urban development, the inclusion of future residents is vital.

In order to establish the fourth P in PPP research, this article summarises and discusses the participatory and communicative planning theories currently being applied to urban planning processes in Finland. Consequently, we weave a new thread into the cloth of participatory planning as described by planning theorists (Healey, 1998; Taylor, 1998; Forester, 1999; Mäntysalo, 2002; Friedmann, 2005). We point to a new model of PPPs in urban planning and residential development based on the fourth $\mathrm{P}$ : the People. This new $4 \mathrm{P}$ model has been present already in work by, for example, Majamaa et al (2008), Majamaa (2008), Kuronen et al (2010) and Staffans et al (2010) when analysing the development of single cases. Finally, we discuss the practical implications of the $4 \mathrm{P}$ model and consider its value from the perspective of all stakeholders involved in Finnish urban development processes.

In this article we define the prospective inhabitants as those people who are going to migrate or move to a greenfield residential area into newly built homes. The opinions of this first generation of future inhabitants or homeowners is important in establishing the character of the urban development. This is because their initial choice of residential area is more and more a question of lifestyle (Kostiainen, 2002; Scheiner \& Kasper, 2003; / Erø, 2006). Ball (2004) has pointed out some challenges in including the future inhabitants in the development process, but it pays off to search and identify them, as Kuronen et al (2010) point out. 
The following sections present the concepts and an overview of the relevant literature, a separate section on the Finnish planning and participation context, and a summary of the methodology and research material. These three sections are followed by two separate sections on results: the first on accommodating the future inhabitants in the communicative planning theory and the second on including the $4^{\text {th }} \mathrm{P}$ in PPPs in the Finnish context. The paper ends with a section containing the discussion and conclusions.

\section{Concepts and literature}

Previous research based on the theoretical framework of communicative planning has shown that the aim of participation in planning is to increase the legitimacy of planning itself (Healey, 1998; Mäntysalo, 2002; Friedmann, 2005). This is also relevant where this planning takes place under the influence of New Public Management (NPM), which in adopting a managerialist approach to public administration also includes a consumerist approach. The weakness of communicative theory has been the inability to consider in a strategic sense the future inhabitants as one of the primary stakeholders (Kuronen \& Majamaa, 2006). A weakness of NPM is that there are limited means of including people, even as consumers, in managerial processes (consumer satisfaction is frequently used) but these presume existing consumption relationships. Analysing the paper's cases from the future inhabitants' perspective, we can show how PPPs and 4Ps consider and enhance the role of future inhabitants in the urban development process.

If we accept the principles of communicative planning and the involvement of multiple stakeholders, it is clear that actual partnership between different parties is crucial. This is a view that many contemporary researchers share (Hastings, 1996; Ball, 2004; Ball \& Maginn, 2005; Rudlin \& Falk, 2009). However, even if the planning sciences underline the importance of participation and the property development sector emphasises the upsides of partnerships, internationally there is little evidence of the two joining in the same projects. In greenfield areas, residents are strongly underrepresented if the prospective inhabitants are not included in the participation and development process.

Concepts of risk in PPP projects are undeniably complex. PPP procurement is argued to be superior to traditional procurement methods because in PPPs the risk is better allocated to those stakeholders best able to manage it. In recent PPP research this idea has been questioned and it is suggested that considering risk identification, assessment and mitigation is just as important as considering risk allocation (Leiringer, 2006). Nonetheless, under the 4P model the issues of risk are potentially more complex. For example, in traditional PPPs political risk is often borne by the government, construction risk by the contractor and operating risk by the service provider. These risks are related because a government sponsor, a contractor or a service provider will need to retain a monetary allowance to account for unforeseen risks should the project fail during or beyond the construction delivery period. This allowance is a measure of retained risk and is used to allow for unforeseen circumstances across the PPP lifecycle and into the future. Conceivably, under the 4P model, risk allocation is more complex because another party enters the relationship in the form of future inhabitants. In theory, at least, each party may need to hold less retained risk in the future if the inhabitants have been more thoroughly consulted on their future requirements (Raisbeck \& Doloi, 2007). Moreover, in the $4 \mathrm{P}$ model, the risks and moral hazards associated with asymmetric information may be reduced because the other parties are subject to more scrutiny (Kensinger \& 
Martin, 1988). In the 4P model an increased flow of information between stakeholders about the project's future design and operating requirements may mean that there is less likelihood that agents, such as contractors or service providers, will have incentives to act in ways detrimental to the project's sponsor.

\section{The Finnish planning and participation context}

By the dawn of the new millennium, the Finnish Land Use and Construction Act had been renewed. This Act was originally formulated in the post-war era and was formed by, and relied on, strong central government and active land policy (Peltonen et al, 2006). The previous Act was based on the idea that local governments (municipalities) carried on what has been called an active land policy, meaning they either owned or purchased the land before making detailed plans.

In contrast to the much investigated British planning system, where a transition from active land policy to private land development took place in the 1980s (Healey, 1998), Scandinavian and Continental European planning systems are different. In the British planning system, loose plans strengthen the political power and ease land use changes (Kurunmäki, 2005). Debate between loose and tight detailed plans goes on in Finland, as well in the rest of Europe (Rinkinen, 2007). The Finnish system lies somewhere in between an administration-based and an evolutionary market-based planning system (Mäntysalo, 2000).

The main objective of the revised Act was to strengthen the role of public participation and local decision-making (Kurunmäki, 2005; Peltonen et al, 2006). This participation involved all parties; landowners, authorities and relevant Civil Society Organisations (CSOs) were recognised as implicit stakeholders in the planning process. The urban planning department of the municipality has the role of a professional player and is responsible for the actual planning. In undertaking this role the planning department should adopt an objective stance in mediating issues between the other stakeholders. This reflects an incrementalist planning theory view of the planner's role (Taylor, 1998; Allmendinger, 2002). Moreover, the main participating parties are still other municipal departments, such as social and health services, or the education department, even if they do not always produce the services. To underline the importance of participation, the Act insists on compiling a separate Plan for Participation and Impact Assessment (PPIA); this includes the process plan required at the beginning of a project (Government of Finland, 1999; Kurunmäki, 2005). Despite the good intentions of the Act, participation has become an act of faith in development, something that is believed in but rarely questioned (Cleaver, 2001). This is why very little criticism has been directed towards the management of the participating organisations.

The urban planning system in Finland consists of three phases: regional plans; master plans, which usually cover specific areas of a municipality; and detailed plans, which are obligatory in urban areas before any construction work can take place. Municipalities are responsible for making and approving but not executing the detailed plans. Therefore the municipalities' planners aim to achieve a static situation by making tight plans. In the Helsinki metropolitan area, the typical public-led, detailed, planning case consists of three phases: defining objectives and formulating the PPIA; making a draft plan for comments; and then making a plan proposal. This is then approved, first in the city planning committee, then by the city board, and, finally, in the city council. In all of this the usual methods of participation are employed, including public hearings and the possibility of giving a 
written opinion regarding a plan within certain period of time. Discussions are not usually recorded, but the opinions expressed are thought to be received directly by the planners. This kind of participation easily leads to an adversarial and defensive approach (Healey, 1998). The situation is aggravated by the lack of active methods of participation; as a result the Not In My Back Yard (NIMBY) phenomenon is the most common mode of participation.

Rinkinen (2007) has pointed out that the Land Use and Construction Act does not provide each local government with standard planning processes; as a result, detailed planning processes differ widely across local governments and even within individual cities. Nowadays, differences in urban planning processes can be seen as impacting upon strategic choices: will the municipality compete for new inhabitants and taxpayers, or will it not? These factors may explain why it is almost completely in the hands of individual municipalities how participatory processes are organised. It is evident in this context, as Mäntysalo (2002) suggests, that in order to be effective, participation must assume an organised form, which is part of a local bureaucracy and in the hands of organised homeowner groups. In this scenario, future inhabitants, indeed people, do not have an organisation to directly represent them, and if the planners want to get those people's opinions, they can only do so indirectly (Kuronen \& Majamaa, 2006).

\section{Methodology and research material}

For the case comparison we have used two conventional PPP residential master-planned areas in the Helsinki metropolitan area and one area, developed by a 4P model, which we examine more closely. The choice of these areas was based on the following criteria:

- One greenfield project from each of the three biggest local governments (municipalities) of the Helsinki metropolitan area:

- Aurinkolahti, in the City of Helsinki;

- Kartanonkoski, in the City of Vantaa; and

- Hista, in the City of Espoo.

- The future population of the case areas is significant;

- Mainly developed or under development under the new Land Use and Construction Act (2000);

- The land ownership includes both private and public land; and

- The urban planning and development is done in partnership with industry.

Within the Hista case, this paper also draws on its first subarea, Nupurinkartano. One masterplanned residential area from Helsinki, Jätkänsaari, was used as a basis for comparison to show the difference between PPPs and traditional Finnish public-led urban planning processes. Jätkänsaari also differs from the others in that the land is publicly owned by the City of Helsinki, and it is a brownfield project development of Helsinki's old harbour area. However, an important common denominator is 
that there is no existing population in Jätkänsaari. Table 1, below, provides a summary of the characteristics of the areas. 


\begin{tabular}{|c|c|c|c|c|}
\hline & Hista & Kartanonkoski & Aurinkolahti & Jätkänsaari \\
\hline $\begin{array}{l}\text { Landowner at } \\
\text { starting phase }\end{array}$ & $\begin{array}{l}\text { Municipality, two } \\
\text { major and numerous } \\
\text { minor private } \\
\text { landowners }\end{array}$ & Private & $\begin{array}{l}\text { Municipality and } \\
\text { private }\end{array}$ & Municipality \\
\hline Municipality & Espoo & Vantaa & Helsinki & Helsinki \\
\hline Area & 1400 hectares $^{1}$ & 68 hectares & 105 hectares & 86 hectares \\
\hline $\begin{array}{l}\text { Population when } \\
\text { finished }\end{array}$ & App. 17500 & App. 6000 & App. 7000 & App. 14500 \\
\hline $\begin{array}{l}\text { Readiness at } \\
\text { December } 2010\end{array}$ & $\begin{array}{l}\text { General plan } \\
\text { approved by the } \\
\text { council }\end{array}$ & $\begin{array}{l}\text { Area fully } \\
\text { constructed }\end{array}$ & $\begin{array}{l}\text { Area almost fully } \\
\text { constructed }\end{array}$ & $\begin{array}{l}\text { First phases under } \\
\text { construction }\end{array}$ \\
\hline
\end{tabular}

Table 1. Basic information of the case areas

The gathered data is publicly available in planning documents at the municipalities' web pages under the urban development section. The cases have been observed throughout their existence.

\section{Public-led process \\ Case Jätkänsaari}

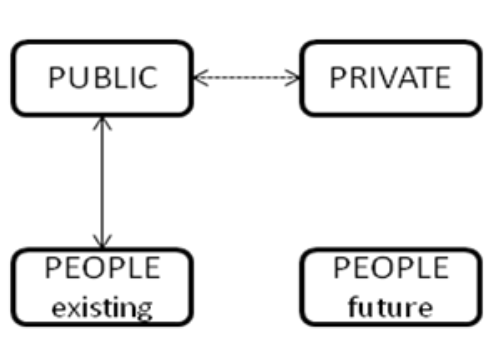

PPP's

Cases Aurinkolahti and

\section{Kartanonkoski}

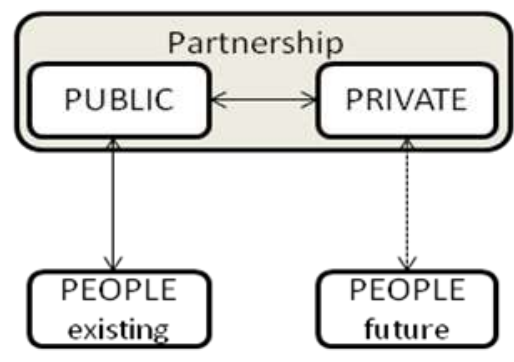

$4 \mathrm{P}$

\section{Case Hista}

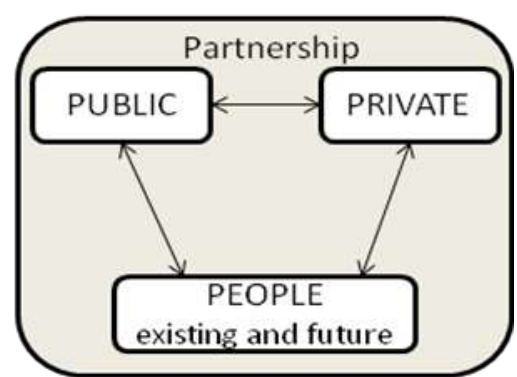

$\longleftrightarrow$ Informal and/or reactive relationship

$\longleftrightarrow$ Formal and/or proactive relationship

Figure 1. The role of the prospective future inhabitants in different urban development processes.

Figure 1, above, presents how the future inhabitants' role differs in each of the selected case studies.

As a theoretical framework, communicative planning can be seen as an action-centred view of a planning system. The aim is to increase the involvement of citizens and stakeholders in the planning process (Taylor, 1998; Forester, 1999). In this framework urban development is understood in its

\footnotetext{
${ }^{1}$ Of which 610 hectares are residential areas; the Hista plan also includes large nature areas.
} 
inclusive form as a way in which a community affects its members' quality of life, environment, and social and economic infrastructure; it is not just the actual plan-making (Friedmann, 2005). In communicative planning theory, dynamic action planning is used as a collaborative process (Healey, 1998), in which the outcomes of the process are created by the stakeholders (Friedmann, 2005). This is underscored by the fact that in Finland special research programmes have been built up to develop new co-operative ways to plan urban and residential development. Until now, the dilemma has been how to know who the future inhabitants will be, as discussed by Ball (2004), and how they can take part in urban development processes and the process of establishing local infrastructure. This dilemma is something this paper addresses.

\section{Accommodating the future inhabitants as stakeholders in communicative planning theory}

This section presents the results of the cases and draws on them to elaborate the $4 \mathrm{P}$ model. In the public-conducted process, as represented in the Jätkänsaari study, the existing inhabitants of Helsinki are heard reactively in the formal participation process. In this process the private sector is usually involved only informally and reactively. If the land is owned by the municipality, the level of cooperation between private and public parties during the planning period is often minimal. The private sector is only included after the planning process is over, and normally via the land sale process. In recent years in the Helsinki metropolitan area this has been done by public auction. For example, in Jätkänsaari, local infrastructure will be developed and delivered by the municipality and the future inhabitants have not had any formal or informal links to the urban development process.

When the urban development is done via the PPP model, the existing inhabitants are again part of the formal process, but this time the private sector plays a proactive and positive role. The public and private bodies are in partnership, making the detailed plan together. In Aurinkolahti, the public body, the Urban Planning Department of the City of Helsinki, had a stronger role than the Urban Planning Department of the City of Vantaa played in Kartanonkoski. In Aurinkolahti, the City of Helsinki did the planning by itself and the future inhabitants did not even have an informal role. In Kartanonkoski, the planning was done by a group of consultants selected through a competition organised by the public and private parties together but paid for by private-sector developers and landowners. In this case the private body was represented by a developer who, outside of the formal planning process, had considered future inhabitants informally as its future customers. This consideration directly influenced the planning details and housing choices of the residential units offered to the market by the developers. In Kartanonkoski, land use contracts were drawn up to finance the economic infrastructure and PPPs were introduced to solve the problem of getting the required social services delivered at the right time for the area. Although PPPs have not been used for the provision of social services, the City of Vantaa has not been able to provide services in a timely manner to its inhabitants by itself.

In Hista, the fourth case study, where the 4P model was used, future inhabitants were considered as one of the stakeholders and they were formally included in the official planning process together with the existing inhabitants. The land in the Hista area is owned by both the private and the public sector. What makes Hista especially interesting, compared to other new areas in the Helsinki metropolitan area, is the organisation of planning. Whereas most plans are drawn up by the municipalities' planners, dynamic action planning, as defined by Friedmann (2005), was adopted in 
Hista. This is a typical difference between urban development processes in Helsinki and Espoo (Phelps et al, 2006). The municipality, developer and the landowners outsourced the actual planmaking to consultants. The City of Espoo concentrated on its authoritative role in conducting the process and overseeing and conducting the formal participation. In addition, the City Planning Committee also decided to form an independent specialist group to discuss the planning principles.

The relationship between the City of Espoo and private landowners and the developer has been authentically co-operative. The 4P-based planning process has, for example, already sped up the project's timetable and shifted the burden of planning costs from the taxpayers to the developer and the landowners. A most interesting part of the process has been the interface between the private sector and the people. The private body arranged several different ways for the existing and future inhabitants to participate, both informally and in response to the process. In the Hista masterplan process, the developer gathered local CSOs, such as scouts, environmentalists and other users of the area, around one table to discuss the area's environmental values. The City Planning Department had thought they would not be allowed to do this due to the objectivity principle. The different relations that identify the future inhabitants and their needs in the planning stage are illustrated below (Figure 2).

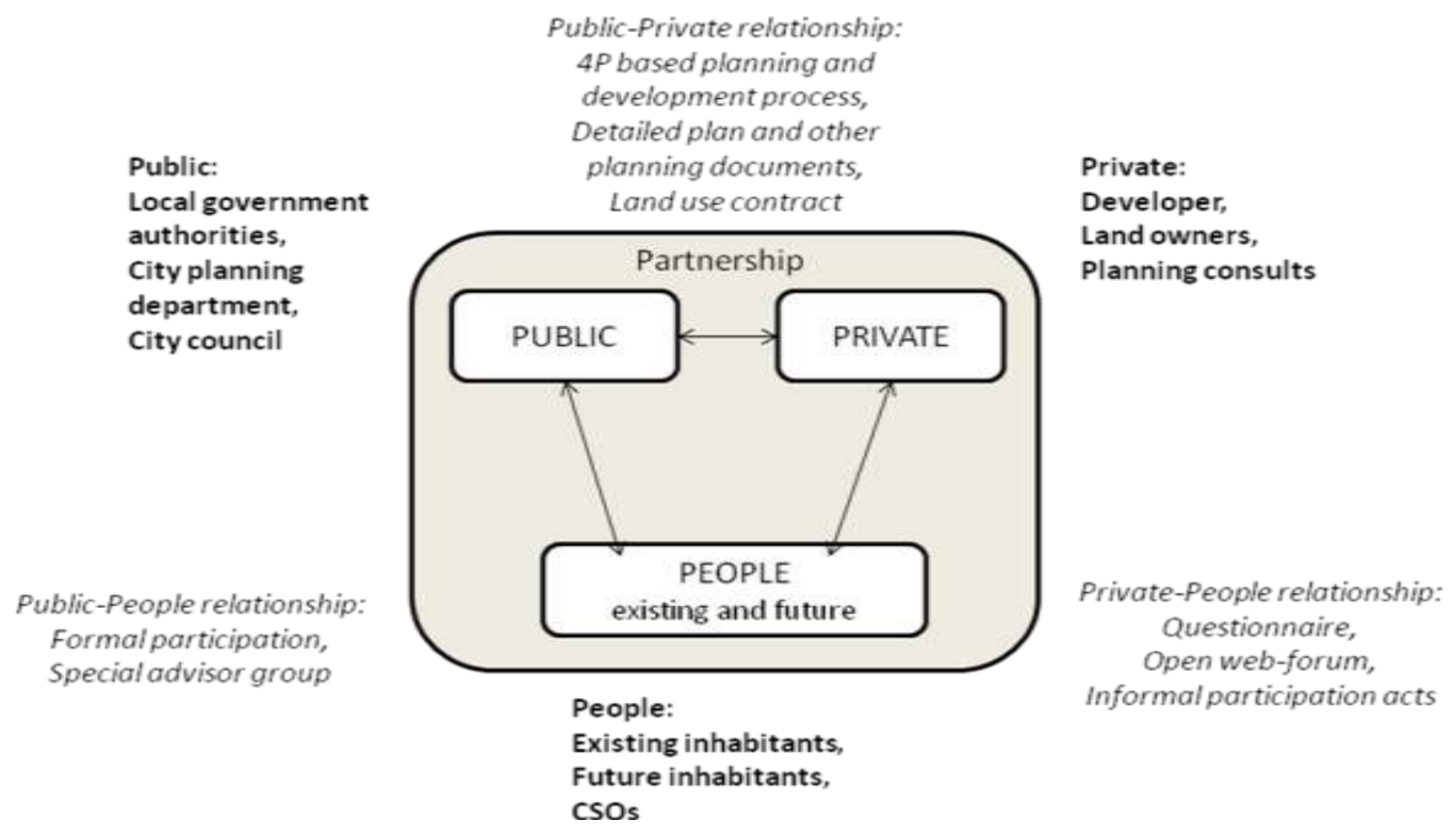

Figure 2. Identification of prospective future Inhabitants. Stakeholders and participation acts in Hista (and Nupurinkartano). After Majamaa et al (2008)

The idea of 4P participation and future inhabitants' identification is to make the process open at all stages, including the planning and construction as well as the operating stage. This method gives the future inhabitants different ways to participate in an open and fluid participation process at all stages of the project life cycle. It is also relevant to avoid the risk of creating a 'formal group of future inhabitants' at the early stages and lose touch with the real needs of future inhabitants - the customers of the public and private bodies (Mäntysalo, 2002). 
An example of how the opinions of future residents were gathered is found in Nupurinkartano, the first phase of Hista, where a two-phase internet questionnaire was conducted, thoroughly reported by Majamaa et al (2008). The pivotal question in the first phase was "What would make Nupurinkartano a good place to live in?" Approximately 200 respondents provided around 800 suggestions. In the second phase these responses were evaluated and prioritised by the respondents. Links to the questionnaire were sent by e-mail to homeowners associations in nearby areas, as these will be likely sources of future inhabitants and stakeholders in every case. The questionnaire was also published on the front web-page of the City of Espoo, as well as in the developer's web-pages. Emails to addresses on the developer's customer register also requested participation in the survey. In this case, approximately 200 respondents participated in the first phase and 150 in the second phase, and the overwhelming majority of the suggestions were positive.

In the 4P model, local residents also play an important role as property owners, or members of the community co-operative. The model was introduced in Nupurinkartano to solve a child day-care problem, as shown in Figure 3.

The municipality was not willing to invest in a new kindergarten, despite the shortage of day-care places in the area. Based on pre-marketing and the questionnaire, it became obvious that this might cause a problem because most of the interested people were families with children. The problem was solved by designating some of the residential units to be used as a kindergarten. This way the community co-operatives will own the premises and can rent them to public or private day-care operators.

In this model the residents will be the owners of the service infrastructure (premises) and the public's role will be administered through service agreements with a community co-operative established for this purpose. Significantly, this kind of solution also gives the local inhabitants themselves the opportunity use the infrastructure outside the times of public use. This kind of $4 \mathrm{P}$ solution with the private-sector provision of public services can mitigate the risk of future inhabitants not having sufficient local services when they need them.

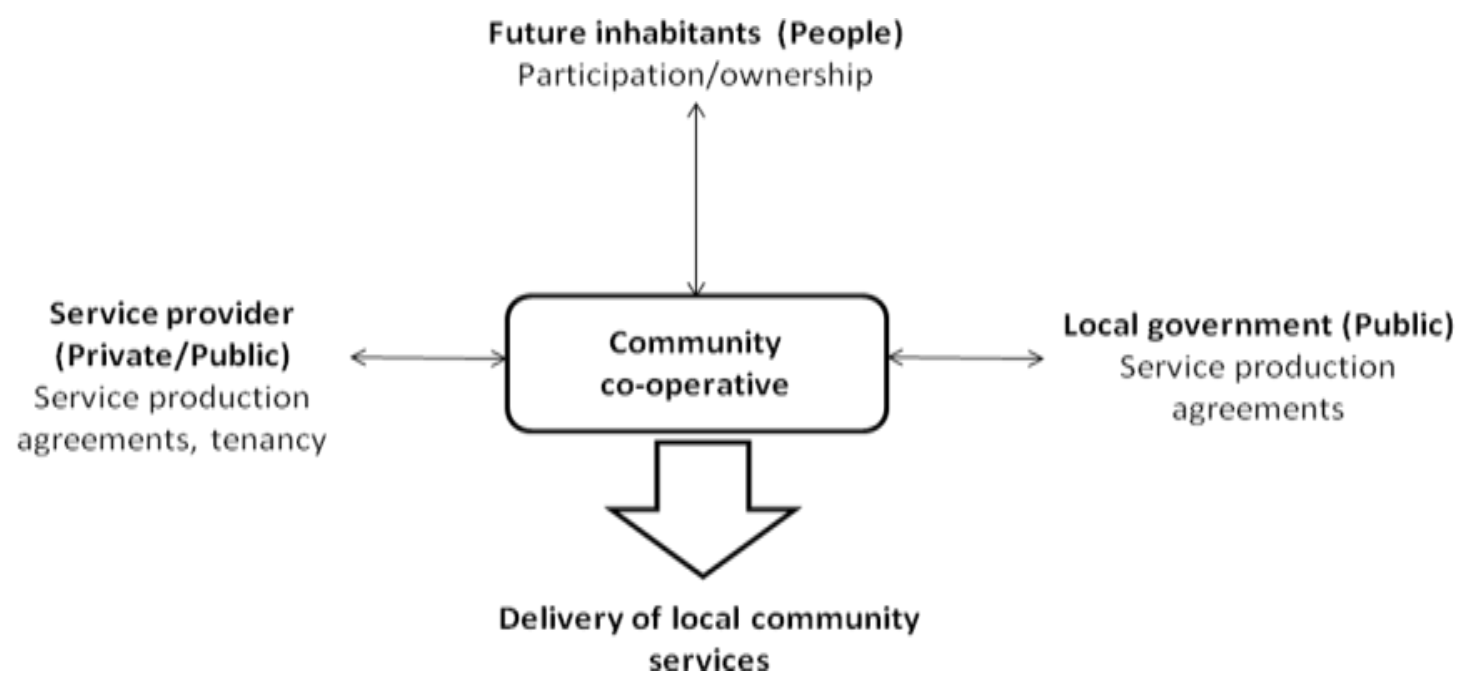

Figure 3. 4P model in providing the local social services, Nupurinkartano day-care as an example. 
From the public perspective, it can be a cost-effective way to offer local social services and increase the community members' participation in producing 'wellbeing' at the local level. In Hista, the 4P model has also been considered as a way to develop larger-scale economic and social infrastructure together with land use contracts. Therefore the $4 \mathrm{P}$ model has the advantage of supporting an evolutionary and ongoing development process to reorganise the risk allocation of PPPs to be optimal and more cost-beneficial for all the stakeholders, including the previously overlooked future inhabitants. This is preferable to simply stopping the development process after the detailed plan is accepted and infrastructure delivered.

\section{Building the 4th P into PPPs in Finland}

By involving the future inhabitants, participation changes from a process characterised by passive and adversarial objects to an active and positive process where the needs of future inhabitants are taken into account. People are thus able to influence their own future housing which, in new residential areas, would then be constructed and delivered by private developers. Future inhabitants, through the $4 \mathrm{P}$ model, can have a stronger influence on their living environment than they would have had if they were considered only as future customers of the developers. In this model both the public and the private sector can integrate participation with place-making and learn earlier what it is that the customers or fourth $\mathrm{P}$ really desire. While traditional PPPs manage financial and construction risk for public authorities, the one thing they are not well equipped to deal with is political risk, which cannot be contracted out to the private sector. Often PPPs are the focus of adverse media attention and debate which can impact on a government's political standing. This adverse attention may arise when one stakeholder in the process makes a loss or carries too much risk (Raisbeck \& Doloi, 2007). The 4P model, through its open participatory planning process, can also reduce the risk of unfavourable political decision-making, as all the stakeholders are more committed to the results. As exemplified at Hista and affirmed at Nupurinkartano, this cannot be done without an authentic mapping of all stakeholders. Moreover, both the strong stakeholders and the weaker ones must be considered, as this is very important in any application of the theory of communicative planning (Healey, 1998; Flyvjberg, 1998; Mosse, 2001).

The Hista area will be one of the largest greenfield residential development areas in the Helsinki metropolitan area in the next decades. In this context, the 4P model has created possibilities for engaging new proactive and positive participation methods and solutions, not only for urban planning but also for local economic and social infrastructure. These methods and solutions can also be used to establish better risk allocation between the political, administrative, developer and enduser parties and to create innovative and cost-beneficial ways to produce economical local social services.

The findings of this paper amplify the impression that collaborative and participatory planning, multiple stakeholders and partnerships enable a holistic view to be used in planning. The public sector, the private sector and the people each bring new knowledge to the table in order to create liveable residential areas (Godschalk, 2004; Friedmann, 2005). By considering the future and existing inhabitants, the fourth $\mathrm{P}$, or people, as a significant stakeholder in the urban development process, and by using the 4P model as a foundation for an action planning method, we can turn participation from merely opposing all changes into creating new possibilities, bringing it closer to collaborative place-making benefiting all stakeholders. 


\section{Discussion and conclusions}

As stated at the outset of this paper, changes in work patterns and workplaces at the global level have affected housing issues at local and regional levels. The Helsinki metropolitan area is the fastest growing area in Finland and one of the fastest growing metropolitan areas in Europe. Over the next 40 years, population growth will remain strong.

The new Public-Private-People Partnership (4P) model proposed here is not a final solution for a complex problem, but it helps to understand the urban planning development process from the endusers' point of view. This is important if Public-Private Partnerships (PPPs) are used to share the costs of rapid urban growth. Until now, the dilemma has been complicated in communicative planning theory and its applications by not knowing who the future inhabitants will be or how they can take part in urban development processes and in processes of establishing local infrastructure. The theory of communicative planning and its applications have missed an important stakeholder - the residential developments' future inhabitants. By involving the future inhabitants as stakeholders in the urban planning process, we can create new methods of participation throughout the process.

This study has managed to establish the prospective future inhabitants as a part of the development process, as was the purpose of the paper. The results of this research will be valuable to future and existing inhabitants of new greenfield residential areas, the public and private professional planners, politicians, developers, landowners and other participants in the urban developing process.

The limitation of this kind of research, and its practical implications, is usually the result of the gap between international research, theoretical process models and the issues surrounding the adaptation and implementation of these models at a local level. In this study we have described the models which can be used to bridge the gap between global theories and local practice. While there will always be differences in legislation and development processes between different global regions, we nonetheless feel that the 4P model can have a wider application outside of the Finnish context.

Identification of future residents is not easy, but the case study of the Hista area shows that it is possible to identify a certain prospective group by combining information from the developer, the local government, and research data from existing areas similar to what is anticipated for the new development areas. As we have indicated, formal and informal participation by future inhabitants and other stakeholders can lead to a development solution where participation encompasses the end-users of the greenfield residential area. It should be kept in mind that there is a distinct boundary, as noted by Healey (1998), between influencing one's living environment as a consumer and as a citizen. This solution can affirm the role of future inhabitants both as citizens and consumers who can have a direct influence on the local economic and social infrastructure.

The circumstances in which the PPP and 4P models have been hitherto used in Finland consist of owner-occupied residential developments where widespread participation is assumed. To correspond with the wider range of development cases such as rental housing or social housing, more cases will be needed. In the future, more research could be conducted to study the economic, social, and ecological outcomes of the $4 \mathrm{P}$ model. This relates to the extent to which the $4 \mathrm{P}$ model can be used to drive innovative practices and develop more desirable neighbourhoods in today's 
networked society. These are ways in which urban research policy, both in Finland and elsewhere, could be shaped in the future. This research could focus on how a more active use of open and wider participation methods would incorporate future inhabitants in urban development processes. Further research could aim to better understand how this model changes PPP risk allocation concepts in both theory and practice.

\section{Acknowledgements}

To be added.

\footnotetext{
'Also Kotler and Lee (2007) refer to four Ps but in an altogether different context. Their Ps are product, place, price and promotion, which are used in marketing theory.
}

\section{References}

AErø, T. (2006). Residential Choice from a Lifestyle Perspective. Housing, Theory and Society , 23 (2), 109-130.

Allmendinger, P. (2002). Planning Theory. New York: Palgrave Macmillan.

Aulich, C.; Halligan, J. \& Nutley, S. (2001). Public sector management, In Australian handbook of public sector management, (eds.), Aulich, C., Halligan, J. and Nutley, S., Allen and Unwin, Sydney, pp. 11-19.

Ball, M. (2004). Co-operation with the community in property-led urban regeneration. Journal of Property Research , 21 (2), 119-142.

Ball, M. \& Maginn, P. J. (2005). Urban Change and Conflict: Evaluating the Role of Partnerships in Urban Regeneration in the UK. Housing Studies , 20 (1), 9-28.

Castells, M. (1996). The Rise of the Network Society - The Information Age: Economy, Society and Culture. Blackwell Publishers.

City of Helsinki Urban Facts. (2010). Helsingin väestöennuste 2011-2050. City of Helsinki.

Cleaver, F. (2001). Institutions, Agency and the Limitations of Participatory Approaches to Development. In B. Cooke, \& U. Kothari, Participation: The New Tyranny? London: Zed Books.

Corrigan, P. \& Joyce, P. (1997). Reconstructing public management; A new responsibility for the public and a case study of local government. International Journal of Public Sector Management, 10 (6), 417-432.

El-Gohary, Nora M., Osman, H. \& El-Diraby, T.E. (2006). Stakeholder management for public private partnerships. International Journal of Project Management, 24, pp. 595-604.

Flyvjberg, B. (1998). Rationality and Power. Chicago, IL: University of Chicago Press. 
Forester, J. (1999). The deliberative practitioner: encouraging participatory planning process. Cambridge, MA: MIT Press.

Friedmann, J. (2005). Globalization and the emerging culture of planning. Progress in Planning , 64, 183-234.

Godschalk, D. R. (2004). Land Use Planning Challenges: Coping with Conflicts in Visions of Sustainable Development and Livable Communities. Journal of the American Planning Association , 70 (1), 5-13.

Government of Finland. (1999). Land Use and Building Act 1999/132.

Grimsey, D. \& Lewis, M. (2002). Evaluating the risks of public private partnerships for infrastructure projects. International Journal of Project Management, 20 (2), pp. 107-118.

Hastings, A. (1996). Unravelling the process of 'partnership' in urban regeneration policy. Urban Studies , 33 (2), 253-268.

Healey, P. (1998). Collaborative planning in a stakeholder society. Town Planning Review , 69 (1), 121.

Kensinger, J. W. \& Martin, J. D. (1988). Project Finance: raising money the old-fashioned way. Journal of Applied Corporate Finance , 1 (3), 69-81.

Kostiainen, J. (2002). Urban Economic Development Policy in the Network Society. Helsinki: Academic Engineers and Architects in Finland - TEK.

Kotler, P. \& Lee, T. (2007). Marketing in the public sector: the final frontier. The Public Manager , 36 (1).

Kotler, P., Asplund, C., Rein, I. \& Haider, D. (1999). Marketing Places Europe, Attracting Investments, Industries, Residents and Visitors to European Cities, Communities, Regions and Nations. London: Pearson Education Ltd.

Kuronen, M. \& Majamaa, W. (2006). The Problem of Future Inhabitants - Finnish Context. Proceedings of "CIRM 2006 Contemporary Issues in Retail Marketing - Destinations and locations: Exploring the Multiple Identities of Place" (pp. 97-103). Manchester: Manchester Metropolitan University.

Kuronen, M., Heinonen, J., Heywood, C., Junnila, S., Luoma-Halkola, J. \& Majamaa, W. (2011). Customerships in Urban Housing Development - a Case Study on Retrofitting a Suburb. Proceedings of PRRES 2011. Gold Coast, QLD: Pacific Rim Real Estate Society.

Kuronen, M.; Junnila, S.; Majamaa, W. \& Niiranen, I. (2010). Public-Private-People Partnership as a way to reduce carbon dioxide emissions from residential development. International Journal of Strategic Property Development , 14 (3), 200-216.

Kurunmäki, K. (2005). Partnerships in Urban Planning. "Development Area" in National and Local Contexts in Finland, Germany and Britain. . Tampere: Tampere University. 
Leiringer, R. (2006). Technological Innovation in PPP's: incentives, opportunities and actions. Construction Management and Economics, 301-308.

Majamaa, W. (2008). The 4th P - People - in urban development based on Public-Private-People Partnership. Espoo: TKK Structural Engineering and Building Technology Dissertations.

Majamaa, W.; Kuronen, M.; Kostiainen, J. \& Heywood, C. (2008). A consumer-oriented technique for planned residential developments. International Journal of Housing Markets and Analysis , 1 (3), 231245.

Mäntysalo, R. (2002). Dilemmas in Critical Planning Theory. Town Planning Review , 73 (4), 417-435.

Mäntysalo, R. (2000). Land-use planning as inter-organisational learning. University of Oulu.

Martinus, P. A.; Stephen O. \& Ogunlana, I. (2006). Good project governance for proper risk allocation in public-private partnerships in Indonesia, International Journal of Project Management, 24, pp.623634.

Mattar, M. H. \& Cheah, C.Y.J. (2006). Valuing large engineering projects under uncertainty: private risk effects and real options, Construction Management and Economics, 24, pp. 847-860.

Mosse, D. (2001). People's Knowledge, Participation and Patronage: Operations and Representations in Rural Development. In B. Cooke, \& U. Kothari, Participation: The New Tyranny? London: Zed Books.

Nisar, T. (2007). Risk Management in Public-Private Partnership Contracts. Public Organization Review, 7 (1), pp. 1-19.

Osborne, D. E. \& Gaebler, T. (1992). Reinventing government; How the entrepreneurial spirit is transforming the public service. Addison-Wesley Publishing, Reading, Mass

Peltonen, L.; Hirvonen, J.; Manninen, R.; Linjama, H. \& Savikko, R. (2006). Land Use Conflicts and their Resolution in Planning: Mapping the Situation in Finland. Helsinki: Finnish Ministry of Environment.

Phelps, N. A.; Parsons, N.; Ballas, D. \& Dowling, A. (2006). Post-Suburban Europe: Planning and Politics at the Margins of Europe's Capital Cities. New York: Palgrave Macmillian.

Raisbeck, P. \& Doloi, H. (2007). Quantification and modelling of retained risk in Public-Private Partnership (PPP) projects. Proceedings of 4th International Structural Engineering and Construction Conference. Melbourne.

Rinkinen, K. (2007). Asemakaavoituksen kestoon voi vaikuttaa (Available in Finnish only). Helsinki: Suomen kuntaliitto.

Rudlin, D. \& Falk, N. (2009). Sustainable Urban Neighbourhood. Building the 21st Century Home (2nd ed.). Oxford: Architectural Press.

Scheiner, J. \& Kasper, B. (2003). Lifestyles, choice of housing location and daily mobility: the lifestyle approach in the context of spatial mobility and planning. International Social Science Journal , 55 (176), 319-332. 
Staffans, A.; Rantanen, H. \& Nummi, P. (2010). Local Internet Forums: Interactive Land Use Planning and Urban Development in Neighbourhoods. In C. Nunes Silva (Ed.), Handbook of Research on EPlanning: ICTs for Urban Development and Monitoring (pp. 80-102). Hershey, PA: Information Science Reference.

Taylor, N. (1998). Urban Planning Theory since 1945. London: Sage Publications Ltd.

Thobani, M. (1998). Private infrastructure, public risk. Finance and Development, 36 (1), pp. 50-53.

Trentmann, F. (2007). Citizenship and consumption. Journal of Consumer Culture, 7 (2), pp. 147-158.

United Nations Population Division. (2007). Urban Population, Development and the Environment 2007.

Van Gramberg, B. \& Teicher, J. (2000). Managerialism in local government - Victoria, Australia. International Journal of Public Sector Management,13 (5), pp. 476-492. 


\section{University Library}

\section{- M M N E R VA A gateway to Melbourne's research publications}

Minerva Access is the Institutional Repository of The University of Melbourne

Author/s:

Kuronen, M;Majamaa, W;Raisbeck, P;Heywood, C

Title:

Including prospective tenants and homeowners in the urban development process in Finland

Date:

2012-09-01

Citation:

Kuronen, M., Majamaa, W., Raisbeck, P. \& Heywood, C. (2012). Including prospective tenants and homeowners in the urban development process in Finland. JOURNAL OF HOUSING AND THE BUILT ENVIRONMENT, 27 (3), pp.359-372. https://doi.org/10.1007/ s10901-012-9269-6.

Persistent Link:

http://hdl.handle.net/11343/282972 